The Geneva Papers on Risk and Insurance, 19 (No. 72, July 1994) 334-356

\title{
Challenge to the Future
}

\author{
by Josei Itoh*
}

\section{Introduction}

Last year in the United States, Bill Clinton was sworn in as the 42nd President; and he is now actively engaged in a series of new policy programs. These policy programs include long-awaited health-care reform and preparations for a new cooperative structure among capitalist societies as witnessed in NAFTA and APEC.

In Europe, the Maastricht Treaty was ratified last year; and while some readjustments still remain to be completed such as the ERM (European Exchange Rate Mechanism), European countries have made another positive step toward their full integration into a union.

Asian countries on their part continue to register sustained economic growth and are in the midst of socio-economic reforms in anticipation of a new age. Last year China explicitly declared in its Constitution the adoption of a Socialist Market Economy system, and it attained a high economic growth rate of 13 percent.

In Japan, the 38-year-long single-party rule by the Liberal Democratic Party finally crumbled in 1993, giving way to the Hosokawa coalition government. Former Prime Minister Hosokawa opted for his resignation only eight months after he took power. But while in office he addressed a number of important issues that would not have been easily placed on any serious political agenda under the LDP rule, such as political reform, tax reform, rice import liberalization and pension scheme adjustment. Moreover his action triggered a very significant realignment of political parties in Japan.

The new government by Prime Minister Hata has agreed to continue Mr. Hosokawa's reformist line and is now expected to revamp the old and rigid framework of partisan interest-oriented political process, and to realize public good-oriented politics that will play an important role for the future development of Japan.

Peter Drucker wrote in his book Post-Capitalist Society, "Within a few short decades, society rearranges itself, its world view, its basic values, its social and political structure, its arts, its key institutions... There is a new world."

Every country in the world is now in the throes of historical self-conversion that is undertaken with the common slogan of "Change and Reform".

* President, Nippon Life Insurance Company, Tokyo. Paper presented at the 30th Annual Seminar of the International Insurance Society, Madrid, June 19-23, 1994. 
Under such circumstances, every industry in the world is making desperate efforts to formulate a future strategy from a global perspective and to build a new frame of reference and values. The life insurance industry is no exception.

The findings of a comparative Delphi study conducted by Andersen Consulting of insurance industries in Japan, the United States and Europe clearly indicate widespread awareness that the industry must:

1) brace for the new age of price competition and

2) develop a new marketing strategy geared to changing and diversifying consumers' needs and wants.

Life insurance executives around the world are striving boldly to address the specific issues of product development, sales channel, services for customers and solvency requirements that meet these two goals in a way appropriate for their respective national or corporate conditions.

The theme of this paper is "Challenge to the Future", and in it will be reflections on present developments and future directions of the life insurance industry in the world. Certain observations will be introduced, bearing in mind the essential question of what strategic directions our industry should pursue in order to contribute to the welfare of people in the world of the 21st century. It is time for top managers to envisage an ambitious and lofty future plan based on an unshakable philosophy and to decide without wavering on those strategic directions needed to pursue and to expedite the plan's implementation. This should be the key factor for success in the 21 st century.

\section{Worldwide currents underlying the life insurance business}

\subsection{Pursuit of efficiency}

The life insurance business finds itself in a period of worldwide turmoil. In the United States, life insurance companies experienced a period of large-scale disintermediation of funds in the early 1980s when the interest rates were high. They found that even in the case of highly protection-oriented products such as whole life insurance, it is indispensable to offer to customers additional values superior to those of other substitute financial products.

This awareness led to revolutionary changes in product development and in sales channel management. New products designed to pursue additional values both in protection and in savings, such as Variable Universal Insurance and Current Assumption, were introduced. There appeared on the scene multi-vendor independent sales channels (e.g., Personal Producing General Agents (PPGA)) and low cost sales channels (e.g., securities brokers) to deliver low-load products, such as individual annuities.

Such changes indicate that the life insurance industry must seek the highest possible business efficiency in the competition with other financial service institutions. Differences in strategic directions will become even more conspicuous in the future: On the one hand, the multiline diversification strategy that pursues an economy of scale as in the case of the Prudential; and on the other hand, the niche strategy that focuses on specific products to exercise efficient resource deployment as in the case of UNUM.

In Europe, banks and other financial service institutions are advancing rapidly into the insurance business as the terms allfinanz and bancassurance indicate. This trend will compel insurance companies to improve on business efficiency in the forthcoming situation of 
more intense competition in the highly savings-oriented European life insurance markets. The move toward further integration of European national markets, as symbolized by the change of appellation from EC to EU, yet further will require better business management efficiency.

In Asian countries, the insurance business continues to register an annual premium income growth rate of over 25 percent, a rate of growth higher than that of their national economies. The rising trend of individual income generated by their economic growth indicates further development of life insurance markets in those countries. But on the other hand, high rates of insurance policy surrender, lapse and turnover of salespeople represent problems yet to be overcome. The increased competition resulting from deregulation of the entry of foreign life insurance companies into Asian local markets is likely to spur further improvement of business efficiency.

Pursuit of enhanced business efficiency is undoubtedly one of the major trends in Japan as well.

The Japanese economy currently is afflicted with the longest and the worst recession since the end of World War II. In the wake of the previous long-sustained high growth, Japanese companies are saddled with surplus production capacity and excess employment that reduce their business profitability. The balance sheets of Japanese companies, including financial service institutions, have turned for the worse due to the burst of the bubble economy and its residual negative impacts.

Hopes for early profitability recovery have been dashed by the strong Yen that came close to 100 Yen to the dollar in August last year and February of this year, damaging export prospects; and adverse weather conditions of a cool summer and a protected rainy season dampened efforts to expand domestic consumption. Worse still, the average return on equity of Japanese businesses has been constantly declining since the $1960 \mathrm{~s}$. The present 3.2 percent return on equity reflects structural problems in Japanese industries. The Japanese economy is indeed caught in what may be termed as a "historic compound recession".

In such an adverse economic climate, the Japanese life insurance industry can only anticipate prospects of zero to low growth. The poor business climate itself drives insurance companies to seek better business efficiency. Moreover, a new age of competition with other financial services is unfolding before life insurance companies in Japan. In the new arena of competition, all the players will vie for the same values under the same conditions and rules or on "equal footing" in a "level playing field".

In the intensifying competition among different financial services, insurance companies must deliver to their customers the largest total value, which may be measured by the following formula: (additional value of products and services) multiplied by (ability of sales force to efficiently deliver the additional value) divided by (price of products and services).

In every aspect of product, services and sales, insurers must seek a yet higher dimension of efficiency, in a situation different from the time when competition was limited to within the life insurance industry.

Such a train of important changes indicates that the life insurance industry, which came into being with the advancement of actuarial skill in the 17th century, must constantly innovate itself through modern technologies such as information processing and financial engineering. It must provide products and services best geared to the market, in the most efficient manner in every aspect of business management. 


\subsection{Changing and diversifying values}

While pursuing efficiency, insurers must not lose sight of the important signals of the changing and diversifying values sought by the customers. Such changes in values may reflect in a global perspective the following developments :

1) The newly arising need to overcome inherent problems of capitalist societies that have been brought to the fore by the passing of the ideological confrontation between capitalist and communist societies and

2) People's aspiration for "affluence" underpinned by a harmony between material wealth and spiritual comfort. Such an aspiration derives from a touch of their regret over their past single-minded pursuit of and heavy dependence on the progress of science and technology.

Such developments challenge insurers to pursue something new that is not defined merely in terms of "efficiency".

The end of the East-West Cold War marked by the demise of the Soviet Union generally is interpreted as meaning the ultimate victory of the Western capitalist system over the Soviet communist system. But a number of problems remain inherent in the capitalist system.

Lester Thurow wrote in his book Head to Head : "If one looks at the growth rate of the non-communist world, it slowed from 4.9 percent in the 1960 s to 3.8 percent per year in the $70 \mathrm{~s}$ and then again fell to 2.9 percent in $1980 \mathrm{~s}$. Free markets also tend to produce levels of income inequality that are politically incompatible with democratic government... Left to itself, unfettered capitalism has a tendency to drift into either financial instability or monopoly".

Capitalist societies must find by themselves solutions to the worldwide problems of population explosion, superannuation of population and poverty. The proposed health care reform in the United States, harmonization of national interests among the EC countries toward their further integration, measures taken in Japan for its problems of an aging population - all of these closely observed events reflect the state of affairs of capitalist societies groping for future directions in addressing those pressing problems.

Ideological confrontation is no longer a relevant frame of reference. Considering the inherent nature of problems common to capitalist societies, it is essential to seek an appropriate equilibrium among capital, labor and consumers in the best way to sustain and enhance the welfare of the entire society.

The progress of modern science helped to increase the material wealth of people considerably. But, on the other hand, new problems of environmental destruction and dehumanization in many aspects of social life have emerged. This has to do with the classic problem since the days of Plato, but the higher degree of people's material demand induced by technological progress now poses an urgent question of how to secure "affluence" underpinned by a harmony between material and spirit for mankind that shares the limited resources of the planet earth. That is to say, people seek an efficiency well harmonized with humaneness and tenderness.

\subsection{Origins of life insurance}

The origins of life insurance can be traced to the system of "Collegia Tenuiroum" of Ancient Rome. This system of a mutual aid cooperative originally was introduced from a 
religious consideration for providing funds for the bereaved family of a cooperative member to conduct a decent religious funeral. The system then gradually evolved into cooperatives for specific professions or trades and provided retirement allowances for members.

The primitive actuarial calculation of these mutual aid schemes was a far cry from the present rigorous calculation, and the financial base of the insurer was weak. But these schemes reflected people's genuine concern to protect their own livelihood, their belief in mutual aid and their trust in the insurer. The essential ideas of insurance are crystallized in these schemes for mutual livelihood protection.

These ancient prototypes of mutual aid schemes developed over time, on the one hand into comprehensive coverage of medieval guilds that offered protection of livelihood for the bereaved family of a guild member and on the other hand into specialty coverages, such as ransom insurance for people going on voyages who were exposed to the risk of being taken hostage by pirates or bandits. The range of insurance coverage continued to expand as new needs of protection arose with the evolution of time.

In Japan, during the Kamakura Period, in the 13th century, mutual aid cooperatives of "Mujin" (Limitless) and "Tanomosi Kou" (Mother and Child Support Chest) developed. Under these schemes, a group of village people pooled a small amount of money and grain into a community chest to help impoverished members of the village. This village mutual aid system gradually expanded. From the 17 th century on, the system was conceived not merely to salvage the indigent, but also to function as a local institution for savings and loans for the farmers who came to be exposed to the spread of a currency-driven economy. These institutions fostered the lofty idea that a large number of people in a group can provide money for the mutual aid of all group members.

In the mid-19th century during the Meiji Period of Japan, Yukichi Fukuzawa, the founder of Keio University in Japan, introduced the modern system of life insurance to Japan. He translated the word "LIFE INSURANCE", faithfully to its original concept, into the Japanese words meaning "assure one's entire life-time". But unfortunately, a different translation meaning "insurance against one's life and death" later took root.

Consequently, until the present, people tended to believe life insurance as meaning only protection against untimely death. But as its development through history shows, life insurance really means "protection and support of one's entire livelihood" that will insure people against various risks that may be encountered throughout life. The spirit of "mutual aid" and "mutual trust" underlies the concept of such insurance. Since life insurance should pertain to every aspect of one's life in terms of both security and happiness, the life insurance industry is, and must be, an "Industry Dedicated to People's Livelihood".

From the above perspective, "Coping with Change" in our industry should reflect fully the nature of the trends that lead into the 21st century, and harmonize two strategic directions :

1) Pursuit of efficiency and

2) Response to changing values and diversifying lifestyles of people.

The overall framework for the strategic thrust of the industry, then, would be to transcend the confines of mere "life insurance" and to realize in practice an "Industry Dedicated to People's Livelihood" that can provide comprehensive protection and affluence of livelihood founded on the spirit of mutual aid and mutual trust. 
Now the real moment of truth is coming for insurance executives to show their true caliber and competence in providing answers to the essential question of how to develop an optimal balance between the two strategic directions and how to formulate an unshakable strategy that will open the door leading to a bright future in the 21 st century.

\section{Life insurance market in Japan}

\subsection{A world leader in life insurance protection}

The Japanese life insurance industry attained the world's top position in terms of insurance in force in 1987. In 1991 the aggregate in-force amount in Japan was 14 trillion dollars, while the comparable figure of the United States was 10 trillion dollars. (On the basis of premium income, the Japanese figure of $\$ 203.3$ billion almost equals the U.S. figure of 205.7 billion, whereas the U.S. leads in terms of total insurance reserves with $\$ 1.2$ trillion compared to $\$ 800$ billion in Japan.) Measured by the percentage of in-force amount to national income, the Japanese in-force ratio increased rapidly from the 1970s, from 1.3 fold in 1970 to 4.9 fold in 1991 . This ratio is much higher than the average of 1 to 2 fold observed in other countries. Of all the households in Japan, 93.7 percent own some kind of life insurance policy. These measures of high insurance coverage would qualify Japan to be referred to as a "World leader in life insurance protection".

\section{(Exhibit 1)}

Comparative Life Insurance Statistics

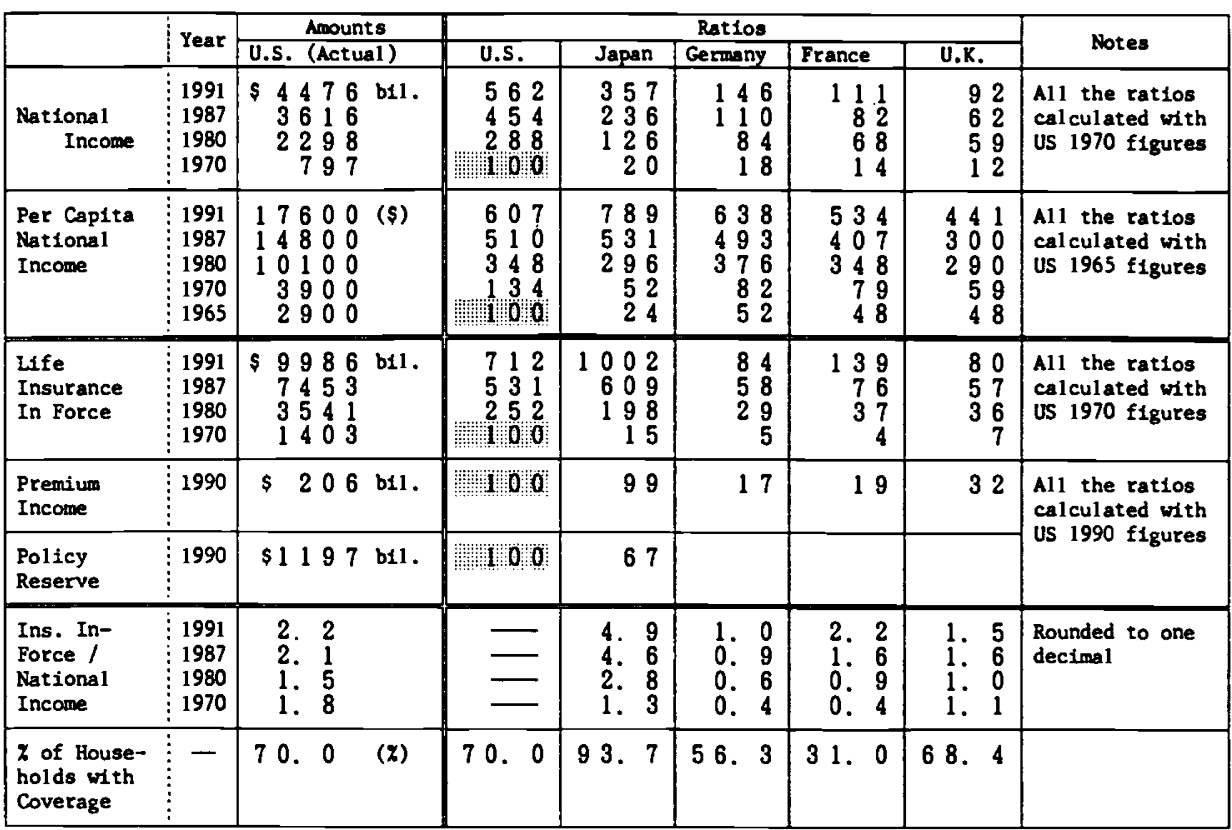

(The Research Institute of Life Insurance Welfare, Japan Institute of Life Insurance) 


\subsection{Product strategy geared to protection needs}

Such a remarkable growth of insurance policy ownership in Japan can be attributed to the strong economic growth of Japan attained since the 1960s and the resulting marked increase in Japanese per capita national income. The majority of the Japanese people began to consider themselves as belonging to the middle class. Spread of the nuclear family system radically changed the social structure of Japan. People developed a sense of necessity that their improved standard of living must be preserved and protected by purchasing large-scale insurance plans.

In response to such increased needs for insurance protection, life insurance companies started in the 1960 s to introduce term insurance riders to be attached to endowment base plans that had represented the main category of life insurance products in the past. In the 1980s, the companies shifted their sales emphasis in regard to the base plan from endowment to whole life insurance with a term rider attached. These new product strategies to offer "larger protection for less premium paid" met the increased needs of consumers and proved to be a great success.

\subsection{Utilization of women sales force}

In the sales field, the decisive factor that helped sustain the remarkable growth of life insurance in Japan was the unique sales force of 450,000 insurance salespeople, consisting almost exclusively of housewives. These saleswomen make steadfast door-to-door calls at households located in their respectively assigned territories across the country.

The Japanese insurance sales force composed mostly of women rapidly developed after World War II when the old insurance sales system that had depended on independent general agencies was changed into a direct company-run debit sales system. The new system required a large number of full-time exclusive salespeople to sell insurance and collect premiums. At that time when the labor market for women was still limited, the large-scale recruiting for the insurance sales force attracted a great number of women into the life insurance industry. In the subsequent stage of Japan's high economic growth that caused a labor shortage, life insurance companies continued to expand their sales force by hiring women, as their own saleswomen helped recruit new the labor market for women was still limited, the large-scale recruiting for the insurance sales force attracted a great number of women into the life insurance industry. In the subsequent stage of Japan's high economic growth that caused a labor shortage, life insurance companies continued to expand their sales force by hiring women, as their own saleswomen helped recruit new salespeople by bringing in their own friends or acquaintances. In this way, life insurance sales came to be acknowledged as women's work.

During this period, The Life Insurance Association of Japan and respective life insurance companies exerted constant efforts to improve the quality of the insurance sales system. Such industry-wide efforts to improve the life insurance sales system in Japan were further stepped up as international sales training and award programs were introduced to Japanese insurance salespeople: The Million Dollar Round Table in the United States and IQA citation of LIMRA. Today highly professionally minded saleswomen represent the mainstay of the life insurance sales force in Japan.

\subsection{Active role of foreign life insurance companies in Japan}

In the general picture of product and sales channel developments previously mentioned, 
various life insurance companies displayed their unique characteristics while pursuing their strategies in Japan. This is especially true of foreign life insurance companies to which the Japanese life insurance market has been actively opened. At present, of the 30 member companies of The Life Insurance Association of Japan, eight are subsidiaries or affiliates of foreign companies. (Percentage of foreign ownership: 100 percent - five companies: 50 percent - one company: 30 percent - two companies.) These foreign companies apply newly developed concepts to their product development in the area of non-traditional insurance plans such as "cancer insurance", as well as to their sales channels (e.g. male financial planners, corporate general agencies, mail order) and market segmentation. All foreign companies have achieved measurable success with their new concepts and focussed approaches.

\subsection{Changing trends and diversifying needs of customers: Comprehensive livelihood protection}

In many countries, the aging of the population is advancing rapidly. Japan soon will enter a period of rapid aging of its population to a degree unparalleled in the world. By the year 2000 , people of the age 65 or above will account for 17 percent of the national population of Japan, marking the world's highest rate. By the year 2020, this sector will represent 25 percent of the entire Japanese population. In addition, the further spread of the nuclear family system in Japan will weaken the traditional ties of mutual aid seen in the extended family system. It is anticipated with certainty that each nuclear family unit will become keenly aware of the necessity to take the initiative in preparing for the diversifying needs of its own protection.

(Exhibit 2)

Comparison of percentage of persons aged 65 and over

\begin{tabular}{|c|c|c|c|c|c|}
\hline & \multicolumn{4}{|c|}{ percentage of persons aged $65 \&$ over } & $\begin{array}{c}\text { years required } \\
7 \% \rightarrow 14 \%\end{array}$ \\
\hline Japan & $4.9 \%$ & $7.1 \%$ & $17.0 \%$ & $25.5 \%$ & 25 \\
\hline France & 11.4 & 12.9 & 15.6 & 19.5 & 125 \\
\hline $\bar{U} \cdot \mathrm{S} \cdot \mathrm{A}$ & 8.1 & 9.8 & 12.4 & 16.4 & 65 \\
\hline $\bar{U} \cdot \mathrm{K}$ & 10.7 & $\overline{12.9}$ & 15.4 & 18.2 & 45 \\
\hline$\overline{\text { Germany }}$ & 9.7 & 13.7 & 15.5 & 19.1 & 45 \\
\hline Sweden & 10.3 & 13.7 & 16.7 & 20.2 & 80 \\
\hline
\end{tabular}

(U.N. Statistics, Population Census of Japan,

Ministry of Health and Welfare (Institute of Population Problems))

In the midst of such a rapid demographic change, the essential function of insurance plans has been shifting from "protection against contingency" to savings accumulation, such as annuity plans designed for life after retirement. Also in anticipation of spending a longer post-retirement life, people's needs of insurance plans to cover health and nursing 
care are rising steadily. In the area of such new insurance plans, mere payout of monetary insurance benefits will not suffice. Adequate systems and physical facilities also are required for the practice of such health and nursing care provided by insurance plans.

\section{(Exhibit 3)}

Most significant issues in the aging society

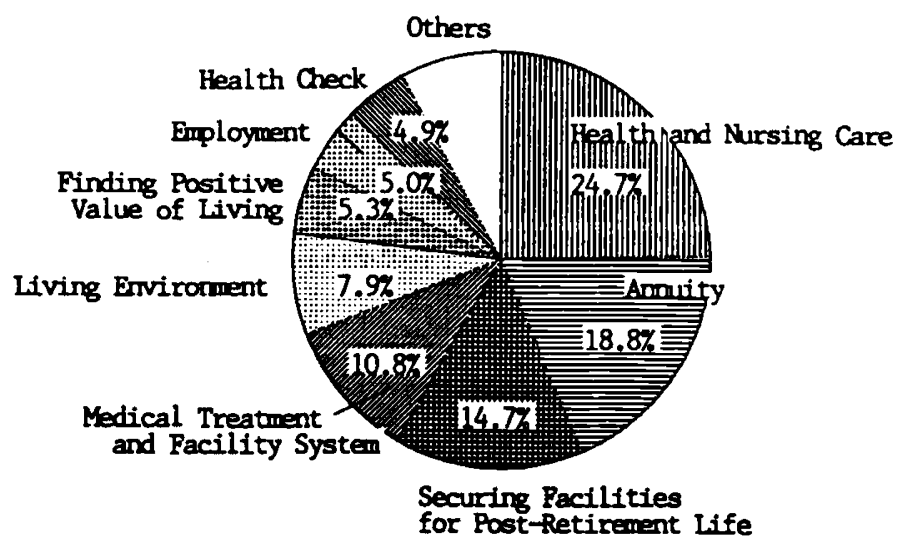

(Prime Minister's office '91)

(Exhibit 4)

Increase of nuclear families

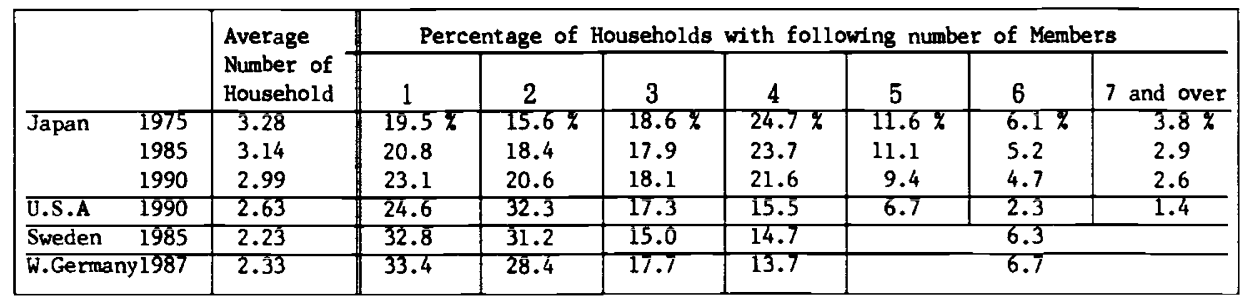

Ministry of Health and Welfare (Foundation Institute for Research of Population Problems, 1993)

The table comparing insurance reserves composition in Japan and the U.S. in 1991 shows that in the United States the reserves from annuity plans (including group annuities) were larger than those of protection plans by a 70 to 30 ratio. But in Japan apparently the part of reserves from annuity plans is still smaller, with a 40 to 60 ratio. This indicates very well that in the coming period of an aging society in Japan the importance of annuity plans will increase rapidly. 
(Exhibit 5)

Reasons for insurance coverage

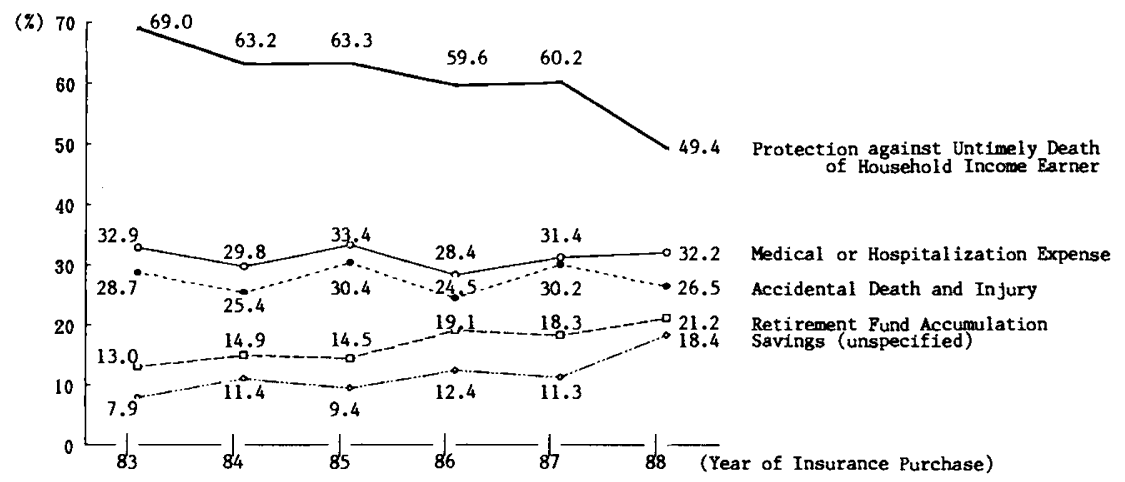

(Japan Institute of Life Insurance, 1988)

(Exhibit 6)

Comparison of US-Japan insurance reserves

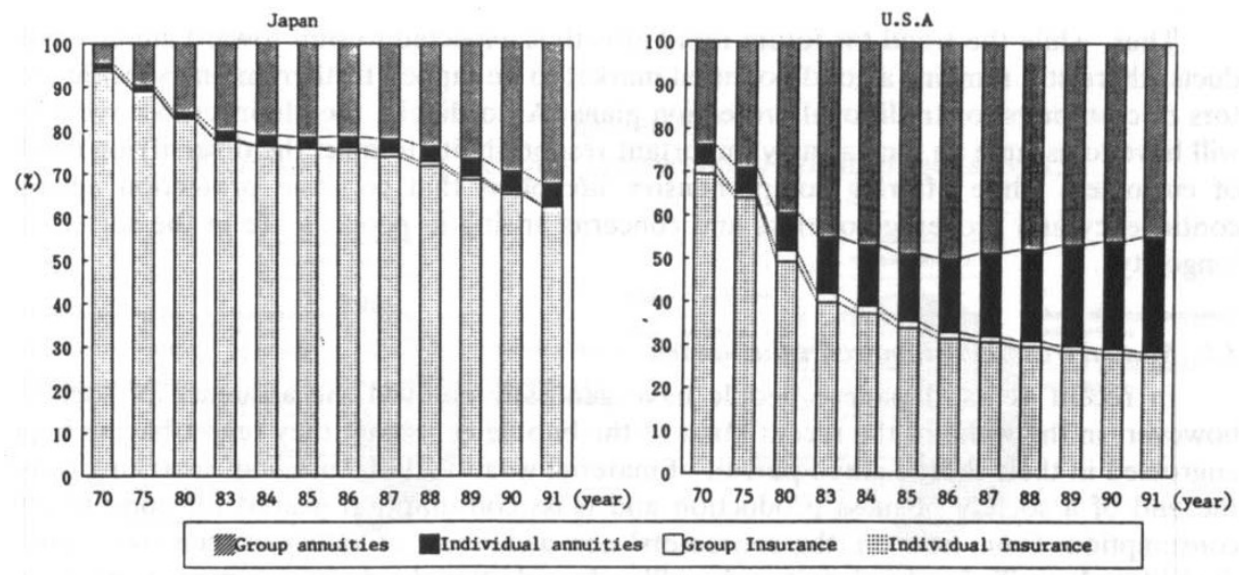

(Japan, U.S.A. Life Insurance Fact Book, 1991)

Meanwhile in the area of traditional protection-oriented insurance plans, the potential female clientele is relatively larger than that of males. This reflects women's advance into the labor market and the development of their independence-oriented mind. Healthy demand for insurance protection by younger people also is expected. 
(Exhibit 7)

Estimated protection market volume (Insurance in force based)

\begin{tabular}{|c|c|c|c|c|c|}
\hline \multirow{2}{*}{$\begin{array}{c}\text { Estimated Percentage of } \\
\text { Market to be Penetrated }\end{array}$} & \multicolumn{5}{|c|}{ Policyholder Age } \\
\cline { 2 - 6 } & 20 s & 30 s & $40 s$ & 50 s & 60 s \\
\hline Male & $39 \%$ & $24 \%$ & $22 \%$ & $22 \%$ & $28 \%$ \\
\hline Female & $40 \%$ & $40 \%$ & $36 \%$ & $38 \%$ & $39 \%$ \\
\hline
\end{tabular}

\begin{tabular}{|c|c|c|c|c|c|}
\hline \multirow{2}{*}{$\begin{array}{c}\text { Estimated Market Volume } \\
\text { ( Yens trillion ) }\end{array}$} & \multicolumn{5}{|c|}{ Policyholder Age } \\
\cline { 2 - 6 } & $20 \mathbf{s}$ & $30 \mathbf{s}$ & $40 \mathrm{~s}$ & $50 \mathbf{s}$ & $60 \mathbf{s}$ \\
\hline Male & 209 & 114 & 87 & 60 & 56 \\
\hline Female & 138 & 106 & 98 & 75 & 62 \\
\hline
\end{tabular}

(Estimates based on Survey by Japan Institute of Life Insurance (1991) on premium amount willing to be paid / Premium actually being paid)

Thus, while the trend for future rapid growth is expected to shift toward annuity products, there still remains a good potential market to be tapped further among specific sectors of customers for traditional protection plans. Accordingly, the life insurance industry will have to assume an increasingly important responsibility to meet the diversifying needs of customers while offering comprehensive life plans that combine protection against contingency and "coverage of risks and concerns arising in people's life in the society of longevity".

\subsection{Mutual trust and enhanced value-added}

In recent years, Japanese people have generally enjoyed the affluence of society; however, in the wake of the recent burst of the bubble economy, they regret having been engrossed in their short-sighted pursuit of material wealth. With such soul-searching came the end of a society of mass production and mass consumption geared for conspicuous consumption. From now on, the consumers' new awareness of values of their own individual lifestyles will develop into trends calling for additional values of consumer products and services. Dentsu Research Institute expressed the emerging trends or "wants" on the part of consumers as follows :

- Consumers evaluate the values-added of a product, such as functional utility, design, information and reliability, based on their personal satisfaction in light of their own individual life styles and values. In other words, they want products and services that offer psychological comfort and values-added that generate their attachment thereto over a long time. 
- Consumer brand selection and loyalty will be determined by the degree of their understanding of and confidence in the lasting values represented by the product, such as stability, credibility, harmony and feeling.

- Diversification of retail channels evidenced by the rise of discount stores has induced the trend toward multiple retail pricing of a product. Consumers now want a pricing system that is reasonable and understandable judged by the utility value of a product.

- With the coming of an information based society, people seek accurate and really useful information. At the same time, people long for human communication underpinned by "relations of trust" as traditional family ties are weakened by the spread of nuclear family units.

What these consumer trends mean to the life insurance business is that customers need, and will demand, pertinent advice upon product purchase ; and they will expect meticulous and quick-responding maintenance services after the purchase as well. Such services need to be provided by insurance salespeople with an understanding of the particular life styles of their customers, which in turn would be appraised as a tangible value added to the product, the policy.

Findings of surveys conducted on insurance consumer behavior indicate that the degree of customer satisfaction is predicated highly on personal customer service or on information supply involving direct contacts between the policyholder and the insurance salesperson. The direct personal contact by the salesperson with the customer is the essential factor that reinforces the customer's trust and confidence in the insurance contract. By responding quickly to consumer needs, the insurance sales force can explore new grounds for delivery of additional values required in the new socio-economic climate.

(Exhibit 8)

Factors influencing customer satisfaction of life insurance services

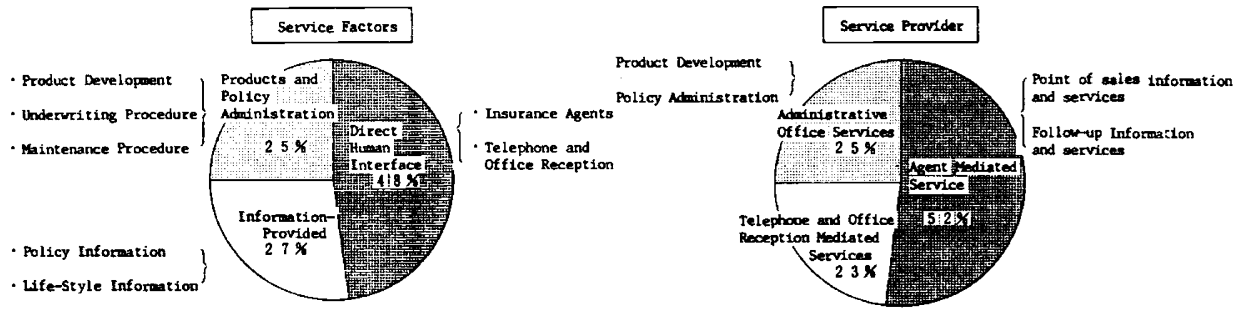

(Nippon Life Service Survey, 1992)

In the new age, life insurance must first and foremost protect in many different ways the economic base of the "affluent life" of the policyholders, and for a price reasonable and acceptable to them. But that is not enough. Comprehensive customer service performed by competent salespeople is indispensable. Such service should be characterized by direct 
human contacts between the salespeople and the customers so that advice and information are delivered personally. Customer trust and confidence always will be the key element that must be secured.

(Exhibit 9)

Consumer needs for comprehensive livelihood protection

\begin{tabular}{|c|c|c|c|c|c|c|c|c|}
\hline \multirow{3}{*}{ Needs } & \multicolumn{4}{|c|}{ Producrs/Services for Monerary Needs } & \multicolumn{4}{|c|}{ Products/Services for Non-Monetary Needs } \\
\hline & \multirow{2}{*}{$\begin{array}{l}\text { Life/ } \\
\text { Non-Life } \\
\text { Insurance }\end{array}$} & \multirow{2}{*}{$\begin{array}{l}\text { Appropr 1ate } \\
\text { Sources } \\
\text { Investment }\end{array}$} & \multicolumn{2}{|c|}{$\begin{array}{l}\text { Key Factor in Select- } \\
\text { Ing Products/Services }\end{array}$} & \multirow{2}{*}{$\begin{array}{l}\text { Profession } \\
\text { al Advice } \\
\text { /Attentive } \\
\text { Services }\end{array}$} & \multirow{2}{*}{$\begin{array}{l}\text { Informs- } \\
\text { ton for } \\
\text { Selection/ } \\
\text { Judgment }\end{array}$} & \multicolumn{2}{|c|}{$\begin{array}{l}\text { Key Pactor in Select- } \\
\text { Ing Products/Services }\end{array}$} \\
\hline & & & A & B & & & c & D \\
\hline Protection from One's own & $44.1 \times$ & $25.0 \%$ & $52.0 x$ & $30.0 \%$ & $32.4 \mathrm{x}$ & $23.5 \%$ & $57.4 \pi$ & $28.7 \approx$ \\
\hline Protection from One's & 57.6 & 27.2 & 48.9 & 36.7 & 45.6 & 31.6 & 65.2 & 29.5 \\
\hline $\begin{array}{c}\text { Pamilly's In jury/Disease } \\
\text { Accumulation of Savings } \\
\text { and Assers }\end{array}$ & 25.3 & 49.4 & 48.8 & 29.3 & 37.4 & 31.6 & 70.5 & 27.3 \\
\hline $\begin{array}{l}\text { Protection from Fund } \\
\text { Defic1t and/or Loan }\end{array}$ & 24.0 & 44.0 & 41.7 & 41.7 & 56.0 & 36.0 & 65.0 & 25.0 \\
\hline $\begin{array}{r}\text { Preparation for Pinancialiy } \\
\text { Stable Post-ret1rement }\end{array}$ & 41.6 & 34.1 & 41.4 & 33.1 & 21.6 & 21.1 & 51.7 & 17.5 \\
\hline $\begin{array}{l}\text { Preparation for Physically } \\
\text { Heal thy Post-retirement }\end{array}$ & 31.4 & 11.7 & 45.7 & 39.2 & 33.4 & 15.1 & 45.8 & 15.0 \\
\hline $\begin{array}{l}\text { Preparation for Active and } \\
\text { Purposeful Post-ret1rement }\end{array}$ & 27.4 & 19.4 & 38.5 & 27.5 & 20.0 & 13.1 & 30.0 & 20.6 \\
\hline
\end{tabular}

A : Truat and Confidence in the Company

B : Easy to Understand Products/Services

C : Trustworthy

D : High Quality

Source: "Survey on Requirements for Comprehensive Livelihood Protection" Japan Institute of Life Insurance, 1988

Life insurance companies in Japan have been striving to improve the quality of their sales staff. Industry-wide common training programs, as well as in-house training systems developed by each insurance company, have been upgraded and expanded steadily. Their present compensation plan is conceived in such a way that the portion of fixed salary increases and the salespeople's revenue stabilizes as they attain certain sales training qualifications.

In the case of Nippon Life (Nissay), highly qualified salespeople deliver personally to their customers several periodicals issued and targeted by the company on specific customer segments, as well as a booklet called "Total Information" that reports the current status of all the customers' insurance policies. Delivery of these periodicals creates opportunities for the sales staff to contact their customers face-to-face and to respond readily to the needs of the customers. As a result of such frequent personal contacts conducted by Nissay's sales staff, customers rate our company highly in their assessment of quality of direct customer services. Survey results show that "service is good", that it is "easy to seek advice" and that the company "provides useful information". But our company should not be merely complacent with such responses from our customers. Rather, we must exert constant efforts to render the valuable asset of our good reputation among our customers into something more visible and more tangible. 
At present Nissay boasts 15 million individual customers and 200 thousand corporate customers. In order to maintain personal contacts with such a huge number of customers, 100 thousand Nissay employees daily expend their utmost efforts. The company receives a monthly total of 1.5 million telephone calls and half a million inquiries from customers through office visits and other means, all asking for advice or inquiring about insurance contracts. While the company has such a firmly established flow of communication with customers, it must strengthen further these relationships through such measures as upgrated policy maintenance service in order to improve the degree of customer satisfaction and to open new channels of communication with potential customers. Accordingly, several company-wide measures to improve customer services have been introduced, as explained in the following chapter of this presentation.

\subsection{Financial services regulatory reform}

In Japan competition among different financial services is developing steadily. Since 1993, changes in the Banking Law and in the Securities and Exchange Law have opened the way for banks, securities firms and trust banks to enter into each other's business territory by way of their respective subsidiaries.

As for the insurance business, in 1991 the Insurance Council submitted to the government a proposal for major revisions of the existing Insurance Business Law; and preparatory work is currently underway for a wholesale revision of the law for the first time in 50 years. After revision of the law, mutual access to various business territories will develop, not only between life and non-life insurance businesses, but also between insurance businesses and securities firms and trust banks.

Specific rules on such anticipated mutual access in financial services have not yet been determined. But in view of the expanding market of savings and annuity plans, those financial institutions that are not legally allowed at present to offer annuity products will insist strongly on their entry there. From a mid- to long-term perspective, the forthcoming mutual access for all the financial institutions in this particular market will intensify competition which, in turn, will further press the parties concerned to improve the efficiency of their business operations. Insurance companies for their part will have to consolidate their business strength to cope with possible price competition and to respond in a flexible manner to changing business environments.

\subsection{Changes affecting insurance sales channels}

\subsubsection{Shift towards the work-site market in large cities}

Notable changes affecting insurance marketing have appeared in two ways:

- A division of the market into two categories: the growing market of cities where population grows due to an influx of people from rural communities versus the stable market of local communities.

- A growth of the so-called work-site market owing much to the increasing percentage of the population that are office employees.

The population has concentrated into the three major metropolitan areas of Japan: Tokyo, Osaka and Nagoya. A total of 48 percent of the Japanese population resides in the areas surrounding these three major cities. Even outside of these three metropolitan areas, population is concentrating notably into middle-sized core local cities. 
(Exhibit 10)

Likelihood of life insurance entry by other financial institutions

Individual Annuities

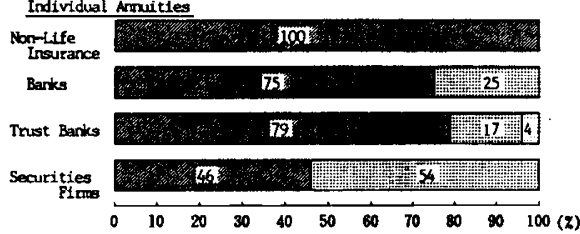

Grovp Ampities

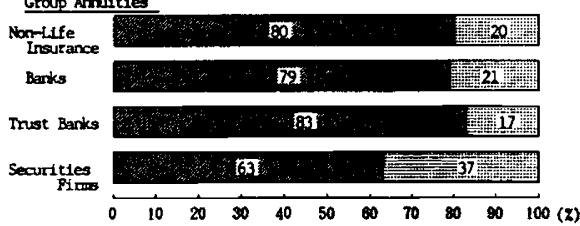

Selling of Insurance

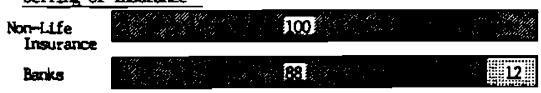

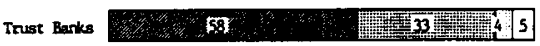

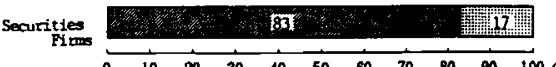

(Andersen Consulting "Delphi Study on Insurance Industry in Japan, 1991")

(Exhibit 11)

Population shift to 3 major metropolitan areas

\begin{tabular}{|c|c|c|c|c|c|c|c|}
\hline & \multicolumn{7}{|c|}{ (Ten Thousand persons) } \\
\hline & 1960 & 1970 & 1980 & 1990 & $\begin{array}{l}20000 \\
\text { (Estimate) }\end{array}$ & $\begin{array}{l}20010 \\
\text { (Est Imate) }\end{array}$ & $\begin{array}{l}\text { ※Geographic } \\
\text { Area( }(\mathrm{sq} . \mathrm{km})\end{array}$ \\
\hline $\begin{array}{l}\text { Tokyo Area * } \\
\text { Osaka Area * } \\
\text { Nagoya Area * }\end{array}$ & $\begin{array}{c}1.738 \\
(18.3 x) \\
1.295 \\
(13.6 x) \\
737 \\
(7.7 x)\end{array}$ & $\begin{array}{c}2.341 \\
(22.6 x) \\
1.603 \\
(15.5 x) \\
861 \\
(8.3 x)\end{array}$ & $\begin{array}{c}2.870 \\
(24.5 x) \\
1.843 \\
(15.7 x) \\
987 \\
(8.4 x)\end{array}$ & $\begin{array}{l}3.180 \\
(25.7 x) \\
1.934 \\
(15.6 x) \\
1.055 \\
(8.5 x)\end{array}$ & $\begin{array}{l}3.477 \\
(27.3 x) \\
1.987 \\
(15.6 x) \\
1.110 \\
(8.7 x)\end{array}$ & $\begin{array}{l}3.747 \\
(28.7 x) \\
2.024 \\
(15.5 x) \\
1.146 \\
(8.8 x)\end{array}$ & $\begin{array}{l}13.142 \\
(3.5 \%) \\
22.426 \\
(5.9 \%) \\
20.938 \\
(5.5 \%)\end{array}$ \\
\hline Total Population & 9.509 & 10.352 & 11.706 & 12.361 & 12.739 & 13.040 & 377.750 \\
\hline $\begin{array}{l}\text { Percentage of Population } \\
\text { (In } 3 \text { major cities) }\end{array}$ & $39.6 x$ & $46.4 x$ & $48.7 \%$ & $49.9 x$ & $51.6 x$ & $53.0 x$ & $15.0 x$ \\
\hline
\end{tabular}

* Tokyo Area .... Chiba.Sa1tama.Kanagawa prefectures.Tokyo metropolitan area

- Osaka Area .... Osaka,Kyoto.Hyougo,Nara,Shiga prefectures

- Nagoya Area ... Alcht.Mie.Gifu prefectures

Population Census of Japan. "992 Population Projection for Japan" Ministry of health and Welfare

(Foundation Inst1tute for Research of Population Problems). Geographical Survey Institute 
Company employees represent 80 percent of the total Japanese population that are active and gainfully employed. This has led to an increasing share of insurance sales generated from work-side sales to these company employees. Thus, the importance of work-site marketing is increasing. Viewed from a different angle, this development means that a larger number of women now are engaged actively in office work, and married women no longer are staying home merely doing household work. Traditional door-to-door insurance sales no longer can reap as much results as it used to do. The housewives the insurance salespeople go after are no longer at home.

(Exhibit 12)

Increase in percentage of company employees

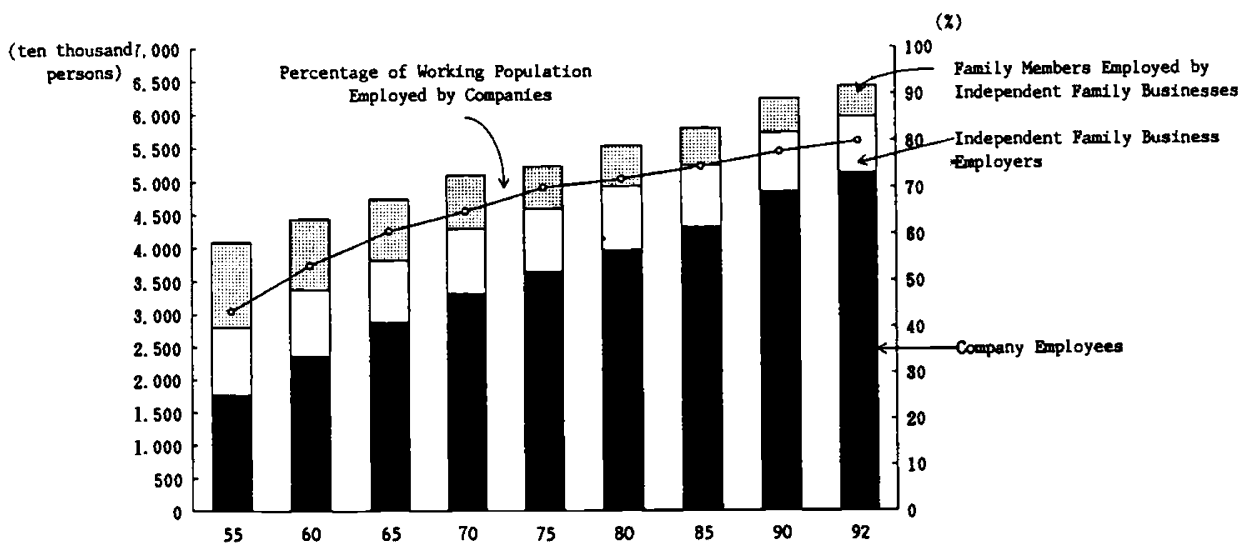

(Economic Planning Department "White Paper on National Life, 1993")

\subsubsection{Changes in sources of recruits for the insurance sales force}

The quality of the insurance sales force has been enhanced by the massive entry of highly educated women into the labor market. Their positive attitude toward work also has contributed to improving the quality of the insurance sales force. In recent years as many as 40 percent of female high school graduates go to college (including two-year junior colleges), boosting their total college entrance rate to a level equal to male graduates. In 1990, as many as 80 percent of new female college graduates secured a job upon graduation, catching up with men in the rate of securing jobs upon graduation. In light of such a development, the new working women seek to apply fully their aptitude and competence to their jobs and to realize their own "self-actualization" to a greater extent than the previous generation of working women.

As more and more highly-educated women seek active roles in their work, positive recognition of insurance sales as a job befitting them will increase steadily. Insurance sales can provide them with a pride of being a "banner carrier of the industry dedicated to the 
enhancement of people's livelihood". Acting as her customers' own personal agent, an insurance saleswoman can offer advice to her customers on a wide range of matters from protection to savings, and can develop freely her caliber while weaving a wide network of human relations with her customers.

(Exhibit 13)

Female job expectations and image of life insurance sales as a profession

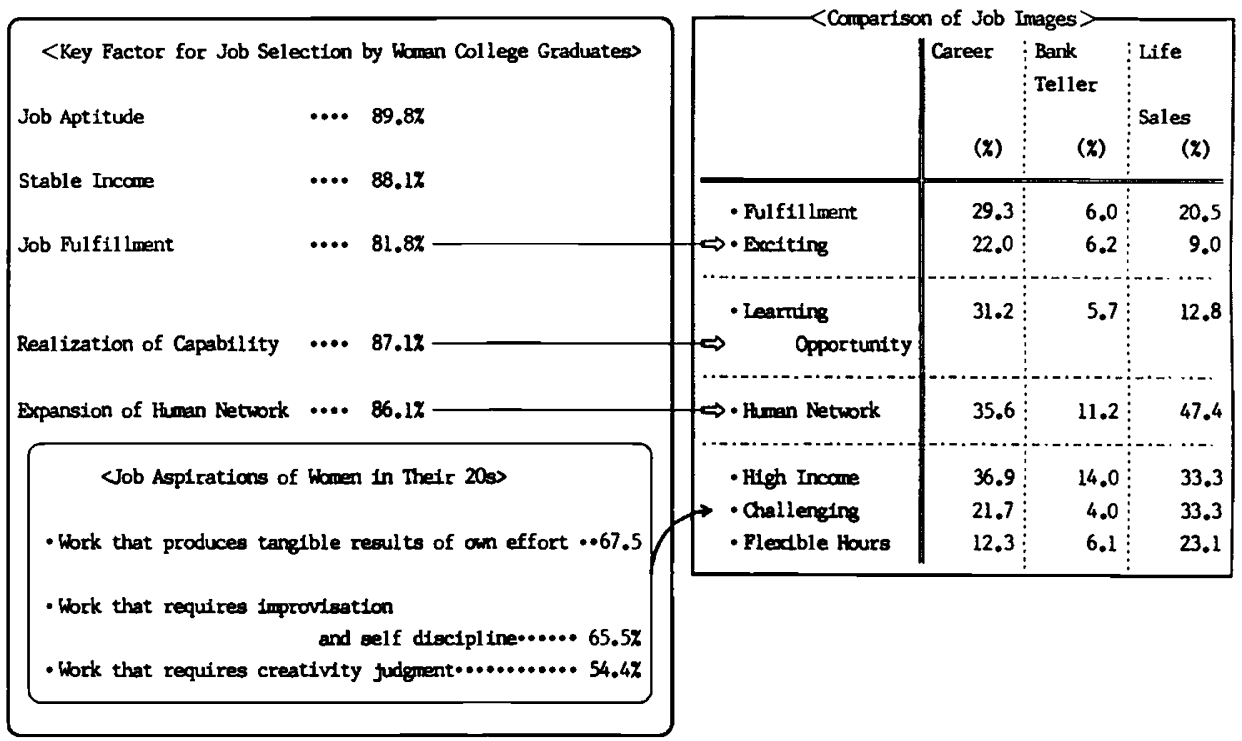

- Key Factor for Job Selection by Whan College Graduates.... Nissay Research Institute ('92)

- Comparison of Job Images .................................. Nssay Research Institute ('92)

- Job Aspirations of Wanen in Their 203 .................... Recruit Research ('92)

4. Coping with change-strategic directions toward the 21st century and introduction of Nissay's strategy

\subsection{Strategic directions toward the 21st century}

In the foregoing paragraphs, observations have been made about developments in the life insurance industries of the world and in the Japanese life insurance market. At such a juncture of epochal structural changes, life insurance companies cannot survive merely by extrapolating their past success stories into the future. To win the day in the intensifying competition, we not only must respond in a meticulous manner to changing values held by consumers, but we also must improve our business efficiency. We must maintain an equilibrium between these two tasks and by so doing, envisage a new horizon for the industry. On the threshold of the 21 st century, the following should be the essential directions of a dynamic strategy for the life insurance industry: 


\subsubsection{Direction to pursue as an "industry dedicated to people's livelihood"}

- In addition to offering protection against risks, life insurance companies must develop for customers a portfolio of products and services that cover every aspect of their life style needs, including building and management of their financial assets. To do so, we must enhance and expand our abilities in investment and risk management.

- By developing our business into such areas as health and fitness or comprehensive services for the elderly, insurance companies must address the issue of "how to enrich the longer life after retirement".

- We must enhance our function as readily available consultants capable of actively advising on how to enrich one's life in accordance with one's life individual life style.

\subsubsection{Direction to pursue as a "human resources industry"}

- Insurance companies must establish an optimal sales system formation and product portfolio that correspond best to the changing market and customer values.

- We must construct an efficient and powerful sales force that can win the competition among different financial services.

- We must realign our education, training and compensation system so that it will allow all individual employees to display the best of their talents and abilities.

\subsubsection{Direction to pursue as a "service industry"}

- Insurance companies must secure the position as "the best service industry" that cannot be matched by any other financial service institutions through value creation for customers, such as improved quality of direct interface with customers and delivery of accurate and useful information that will reinforce the "trust and confidence" of customers.

Certain operations of Nissay will now be introduced as a possible reference to what may be considered specific implementation along the lines of these strategic directions.

\subsection{Introduction of NISSAY's corporate strategy}

\subsubsection{Sales channel revolution - strategy of "Branch" operations}

It has been said, both in the East and the West, that "an insurance policy is sold, not bought". In the midst of current changes of the insurance market structure and values of customers, the front line sales force must respond dynamically and flexibly to the changing trends of the new age. In this regard, the most important task today is to improve and expand past successful sales strategies and to re-adapt them to the newly rising needs of customers. In other words, the new management strategy must focus on establishing a future-oriented sales channel that is geared to winning the trust and satisfaction of customers.

In 1979, as part of its new sales strategy deployed in major cities, Nissay introduced a new sales force under the name of LIEVE, a composite word of "Life" and "Eve". Under this system introduced in the three major metropolitan areas of Tokyo, Osaka and Nagoya, newly hired female college graduates are pooled into special sales units and assigned to pre-designated corporate work-site markets. These young women are recruited publicly through a rigorous selection process; and they undergo extensive high-caliber training, as well as mutually inspiring and instructive OJT before they are placed in their special units.

The LIEVE sales force which started with only 76 women, today numbers 14,000 and has achieved excellent results in improving the overall quality of our sales force, as they 
expand our sales efforts in pursuing individual customers in corporate work-site markets, as well as corporate accounts. In 1992 the LIEVE sales force was reorganized into an independent sales unit and renamed "Branch", with the intention of further strengthening their ranks to the order of 30,000 .

This concept of "Branch" carries with it the desire to make its operations comparable to those of a branch of a bank. The "Branch" is to be staffed by highly productive employees who will be delegated responsibilities higher than those of the existing regional sales offices.

This "Branch" strategy is intended to respond to the changing needs of a new age through a wholesale reorganization of the present sales system. The new group of female college graduates will engage in sophisticated and dynamic sales activities on a scale comparable to the mainstay of our existing sales units composed mostly of 70,000 housewives assigned to door-to-door sales territories. They will serve as the catalyst for a dynamic change in our sales formation.

The purpose of introducing the "Branch" strategy is as follows: In Japan where women still face hidden barriers in the labor market, the "Branch" system will offer to women a workplace where they can develop a sense of self-actualization or full self-achievement with managerial or specialist promotion opportunities. This system will foster high morale in a highly qualified sales force which not only will stimulate positively other existing segments of the sales force but also will lead to overall upgrading of the entire sales force. In the future, the work hours of the sales force will be made more flexible (in consideration of childrearing) so that they can make compatible their work and household management along the development of their life stages. Such a concept as this "Branch" system of saleswomen indeed reflects the bold dream to help women fully realize their potential at their work in a way far surpassing their possibilities as ordinary office clerks.

In the looming intense competition among different fields of financial services, in order to overcome our competitors from other financial services, it is indispensable for us to develop an army of highly competent salespeople who can offer appropriate advice to customers and function as financial planners. They should be able to cover a wide range of financial issues and to supply their customers with relevant information on estate tax, health and fitness, services for the elderly, etc. This "Branch" strategy carries far-reaching implications because it is our means of preparation for the development of a sales force that can perform aggressively in the future environment of cross selling among different financial services.

This "Branch" strategy also means that the company is building a cost/effect-conscious strategy to explore urban markets with the deployment of a higher qualified sales force. The market is being segmented between a growing market on the one hand and a stable market on the other. The "Branch" strategy is one means to concentrate on the growing urban work-site market by reorganizing the sales force into an efficient system best tailored to serve specific target markets, such as sales units dedicated to cultivating new work-site markets or to further develop existing ones.

By this "Branch" strategy, we hope to mobilize two different corps of sales forces in urban markets. In the future the "Branch" may be structured into an independently incorporated business entity. At the same time, in the long-growth rural markets, the organization of existing regional sales offices may be streamlined to give way to an independent general agency system. 


\subsection{Customer services revolution - realization of 20 million individual and 300 thousand cor- porate customers}

\subsubsection{The foremost quality service}

In formulating our future management strategy, while we proceed with the radical reform of the sales system as seen in the introduction of the "Branch" concept, reform of every sector of our company, including the head office structure, is essential so that the entire company can respond efficiently to customers.

In addition to the daily activities of its sales people, NISSAY receives a monthly total of one and a half million telephone calls and half a million inquiries by office visits and other means from our customers, asking for advice or inquiring about their insurance policies.

Such an enormous channel of communication with customers is a precious asset accruing to NISSAY with no additional sales efforts expended on our part. From such a viewpoint, NISSAY is placing more emphasis on "pull orientation" than on the "push orientation" of the past, and stepping up its effort to realize the "Foremost Quality Service" network with the highest trust and confidence from its customers. With such a customer service revolution in line with the underlying principle of "customer's satisfaction must come first", NISSAY hopes to expand its total clientele from the current 15 million individual customers plus 200 thousand corporate customers to 20 million individual customers and 300 thousand corporate customers by the year 2000 .

Former Chairman of Scandinavian Airlines Jan Carlzon wrote in his book Moments of Truth that the vertical moment in which the quality of customer services of a company is assessed, is crystallized into the time an employee spends in direct contact with a customer, or a mere 15 seconds in the case of his company. As a part of NISSAY's attempt to improve customer services, all of its executives were asked to come up with ideas to answer the question "What are our moments of truth?" and invited to present constructive proposals and suggestions. A company-wide "Best Service Campaign" also has been organized. Such measures are intended to awaken the employees to the needs of better services to satisfy our customers fully, as well as to re-engineer our entire customer services procedure and infrastructure.

So far, as a result of this campaign, we have been able to reduce the number of different application forms and sheets drastically from 46 to 6 , thereby greatly improving our policy administration process. Now the entire issuance procedure of a policy is completed in two days, compared to one week that was previously required. We also have received very favorable comments from our customers with respect to the responsiveness of our telephone and office reception services.

The needs and wants of our customers that are conveyed to the company through our constant efforts to enhance customer interface will open the way to further the development of products and services that are finely tuned to customer perspectives.

Furthermore, to offer higher-quality comprehensive consulting services in a more comfortable setting to its customers, NISSAY has established six customer service centers with high caliber personnel and facilities which are called "Life Plazas". At these service centers, a wide variety of consulting services on life insurance, asset formation and tax planning are offered free of charge, and seminars by specialists are held regularly. Services at Life Plazas have been highly appreciated by our customers. 


\subsubsection{Segmented customer information data management (FACE Concept)}

Since 1990, in advance of the above-described improvements in customer services, NISSAY has been compiling information data on its customers' profiles and their families into a computer network under the project name of FACE (Full Access to Customer Expectations).

In the past sales practice of the insurance business, while a salesperson directly contacts customers to sell insurance policies, most information on the customer's profile and his/her family tended to be preserved personally by the salesperson involved and not always communicated back to the company. Consequently, the degree and quality of post-sales services that the customer can derive from the company were mostly predicated on the competence and quality of the salesperson. But in tandem with the on-going improvement of the quality of our sales force, if the company is to provide quality services accompanying its diverse product line that covers traditional protection-oriented plans, asset building plans and other financial products, we need a consolidated and highly sophisticated sales promotion system that is founded on accurate customer information. In this regard, FACE will constitute our principal information data system that can weave yet closer the network of our 15 million individual customers and 200 thousand corporate customers, and that effectively can help our front-line sales force respond to the customer needs.

At present our company issues the Nissay Card that serves as a medium for us to collect and manage detailed customers' information data in a centralized processing system. (The current number of cards outstanding is 1.8 million.) The card also allows the company to extend credit to customers and facilitates delivery of other accessory benefits and services. At the same time, our customers' increasing use of the card through an automatic cash transaction network helps to improve efficiency in policy administration.

The next phase of the FACE program will come in the area of sales support through the introduction of a portable terminal that will read individual identification data contained in the Nissay Card. Such a portable computer system will enable the front line sales force to provide quicker consulting services to their customers. At the same time, the customer information that is fed back to the company through the portable system can be used to manage the extent of customer service activities of the sales people. These measures reflect our continued effort to provide closer support to our sales force.

In addition, such an improved system of database management will make it possible for the company to develop low-cost sales channels such as direct mailing to be operated in tandem with the existing face-to-face selling.

\subsubsection{Ties of mutual trust with society}

In order to become the foremost provider of quality services it is essential that the company win the trust and confidence of the consumer public. In the social context where the consumer public choose their favorite goods and services supplied by specific companies of their choice, those chosen companies must, in their turn, contribute to the social good from a broader perspective beyond their own narrow corporate interests. In this regard, sociocultural activities that contribute directly to the public good must constitute an integral part of the main business activity.

Reference was made earlier to the importance of harmony between material and spiritual affluence. As a good corporate citizen, NISSAY actively and continuously has diverted 
part of its resources for a meaningful social cause that will underpin the public trust and confidence toward the company.

NISSAY has been socially active notably in enhancing the aesthetic and artistic education of school children and in promoting environmental protection. Ever since the Nissay Theater was built in 1963, the company has been actively promoting cultural and theatrical events for the public. As part of our activities in this area, the company sponsors a series of live musical performances under the name of "Nissay Masterpiece Theater" and invites school children to performances staged by the "Shiki Theatrical Company". A total of 5.5 million school children and their parents have been invited to these performances over the past 30 years. Among the children invited, there have been many who were so moved by the musical that they aspired to pursue theatrical careers and eventually became star musical players in their own right.

In 1992 the company also started the "Nissay Million Tree Planting Campaign". The company consumes annually an enormous volume of paper equivalent to 100 thousand trees. This fact has raised our awareness that we must annually reforest at least what we consume. We now collect contributions from all of our 100,000 employees and have launched a campaign to plant 100 thousand trees annually in government-owned lands across the country over the next ten years. Already in the last two years 220 thousand saplings have been planted, and the campaign has been highly praised by the public as an exemplary case of active contribution to society by a business corporation. Our salespeople have found in their contacts with customers that our company is now recognized not only as "a company that sells insurance" but also increasingly and positively as "a company that plants trees".

In 1993 the company further established the "Nissay Green Foundation" to spread the reforestation campaign beyond the Japanese national borders, and now it has begun projects in China and Kenya. In an effort to contribute to the preservation of forestry resources of the entire globe, NISSAY also will expand our reforestation campaign into other areas of the world.

\subsubsection{Comprehensive and multi-faceted business development}

In the context of our response to changes, thus far the sales force and customer services have been discussed, focusing on how to deliver quality services most efficiently to customers and how to win their trust and confidence. The last part of this paper will be a discussion of the directions of NISSAY's comprehensive and multi-faceted development of business linked to the essential long-term concept of the insurance business and geared to delivery of "trust", "security" and "affluence" to its customers.

As mentioned earlier, in the near future Japanese life insurance companies legally will be allowed to expand their business into other areas of financial services by way of their subsidiary operations. Certainly all life insurance companies now are conducting serious indepth strategic studies as to specific lines of business to enter, such as property and casualty insurance or mutual funds. In this regard, life insurance companies must focus on the essential question of what they should provide to their customers in the context of the "Industry Dedicated to People's Livelihood".

In the new arena of competition among different financial services, life insurance companies must take full advantage of their sales channel that is directly linked to customers and strive to deliver further additional values to their customers through their products and 
services. The essential task for each life insurance company is to develop an optimal formula to combine their existing sales channel with a wider product line that results from the mutual access of business. This will reveal the real moment of truth for each company to prove their business acumen.

By way of providing other examples of our business development from a perspective of an "Industry Dedicated to People's Livelihood", our comprehensive services for the elderly also will be explained.

In 1989, our company established the "Nissay Seirei Health and Welfare Foundation" which in turn created in 1992 "Nara Nissay Eden-no-Sono" complex near Osaka. This is a large-scale complex combining housing for the aged, medical and nursing facilities, a health club and a community center. It was approved by the Ministry of Health and Welfare of Japan as the first case of implementation of the Ministry's Well Aging Community Plan for the elderly.

NISSAY will continue to expand its business in the area of facilities and services for the elderly. In-home nursing and medical care or meal delivery services for the elderly will be another possible area of business development. Such services may be combined in a variety of ways with insurance products, including benefits payable in kind. By offering such multidimensional services for senior citizens, we would like to take bold and positive steps to help alleviate the serious social strains stemming from the rapid aging of the Japanese population.

Other than the proposed expansion of its business domain, NISSAY contemplates wider application of advanced telecommunication technology to further improvement of our services and business efficiency. Examples of such application would come in the installation of a telephone service center that instantly responds to telephone inquiries from our customers, an experimental program in telemarketing operated from the telephone center and construction of a sophisticated information network built by the advanced technology of satellite communication or other information delivery systems. Since April 1993, the company started full-scale operations of satellite communication applied to the concepts of "innovation of education" and "innovation in real-time delivery of information". The satellite communication system will pave the way for limitless expansion into many other areas of application.

\section{Conclusion}

The life insurance industry will enter a challenging era, one in which we must cope with change by maintaining a delicate balance between competitive business efficiency and better response to changing and diversifying life styles of customers. This must be done in line with the caring management philosophy that befits an "Industry Dedicated to People's Livelihood".

The top management of life insurance companies have been given a challenging opportunity to enunciate their far-reaching future vision, to make decisions swiftly and to carry out plans steadily so that daring challenges will create a bright future for their companies, as well as for society.

At such a juncture when we all venture into an uncharted new world, it has been a great honor to present this paper. In closing, it is wished that the International Insurance Society, Inc., organized under lofty ideals and principles, may expand further and continue to provide a valuable forum for insurance executives to exchange views and share mutual learning. 